\title{
Obtusaquinone is a cysteine modifying compound that targets Keap1 for degradation
}

Christian E. Badr ${ }^{1 \#}$, Cintia Carla da Hora ${ }^{1}$, Aleksandar B. Kirov ${ }^{1}$, Elie Tabet $^{1}$, Romain Amante ${ }^{1}$, Semer Maksoud ${ }^{1}$, Antoinette E. Nibbs ${ }^{2}$, Evelyn Fitzsimons ${ }^{1}$, Myriam Boukhali ${ }^{6}$, John W. Chen ${ }^{2,3}$, Norman H.L. Chiu ${ }^{4}$, Ichiro Nakano ${ }^{5}$, Wilhelm Haas ${ }^{6^{*}}$, Ralph Mazitschek ${ }^{2,7^{\star}}$, Bakhos A. Tannous ${ }^{\star^{*}}$

${ }^{1}$ Experimental Therapeutics and Molecular Imaging Unit, Department of Neurology, NeuroOncology Division, Massachusetts General Hospital, Harvard Medical School.

${ }^{2}$ Center for Systems Biology, Massachusetts General Hospital, Harvard Medical School

${ }^{3}$ Department of Radiology, Massachusetts General Hospital

${ }^{4}$ Department of Chemistry and Biochemistry, University of North Carolina at Greensboro

${ }^{5}$ Department of Neurosurgery and Comprehensive Cancer Center, University of Alabama at Birmingham, Birmingham, AL

${ }^{6}$ Massachusetts General Hospital Cancer Center and Department of Medicine, Harvard Medical School

${ }^{7}$ Broad Institute of Harvard \& Massachusetts Institute of Technology

* Co-senior authors

\section{\#Correspondence:}

Bakhos A. Tannous, Ph.D., Massachusetts General Hospital, 149 13th Street, Charlestown, MA, 02129 USA, Phone 617-726-6026, E-mail: btannous@hms.harvard.edu

Christian E. Badr, PhD, Massachusetts General Hospital, 149, 13th St, Charlestown, MA 02129, E-mail: badr.christian@mgh.harvard.edu. 
A<smiles>CC(C)(C)CNCc1cc2ccc(=O)c(O)cc2cc1O</smiles>

B
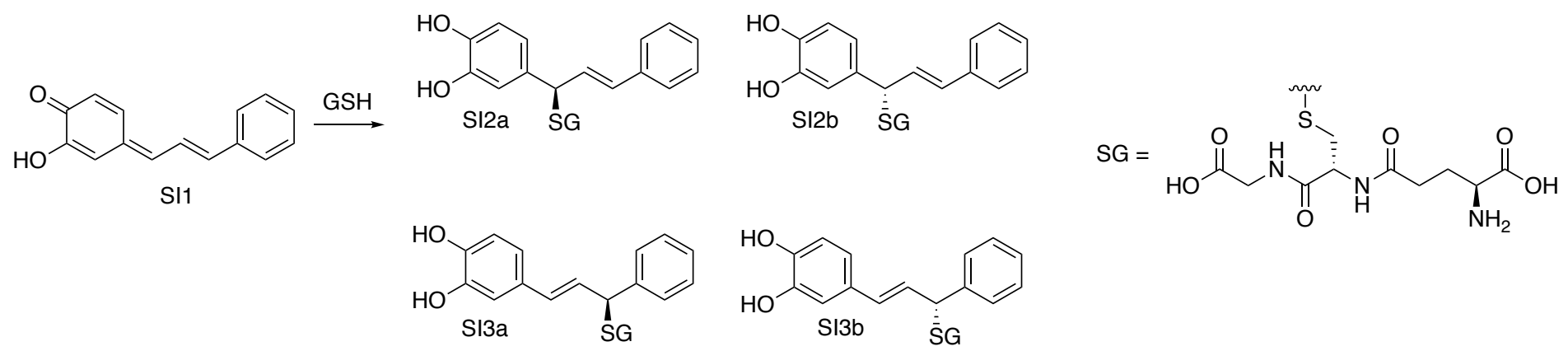

C

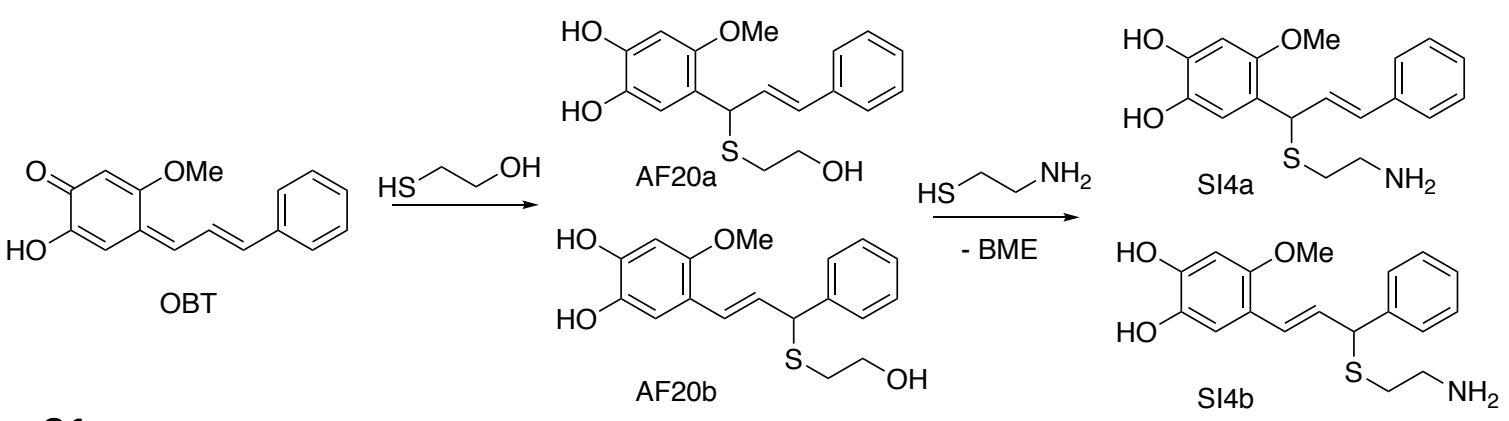

Figure S1 

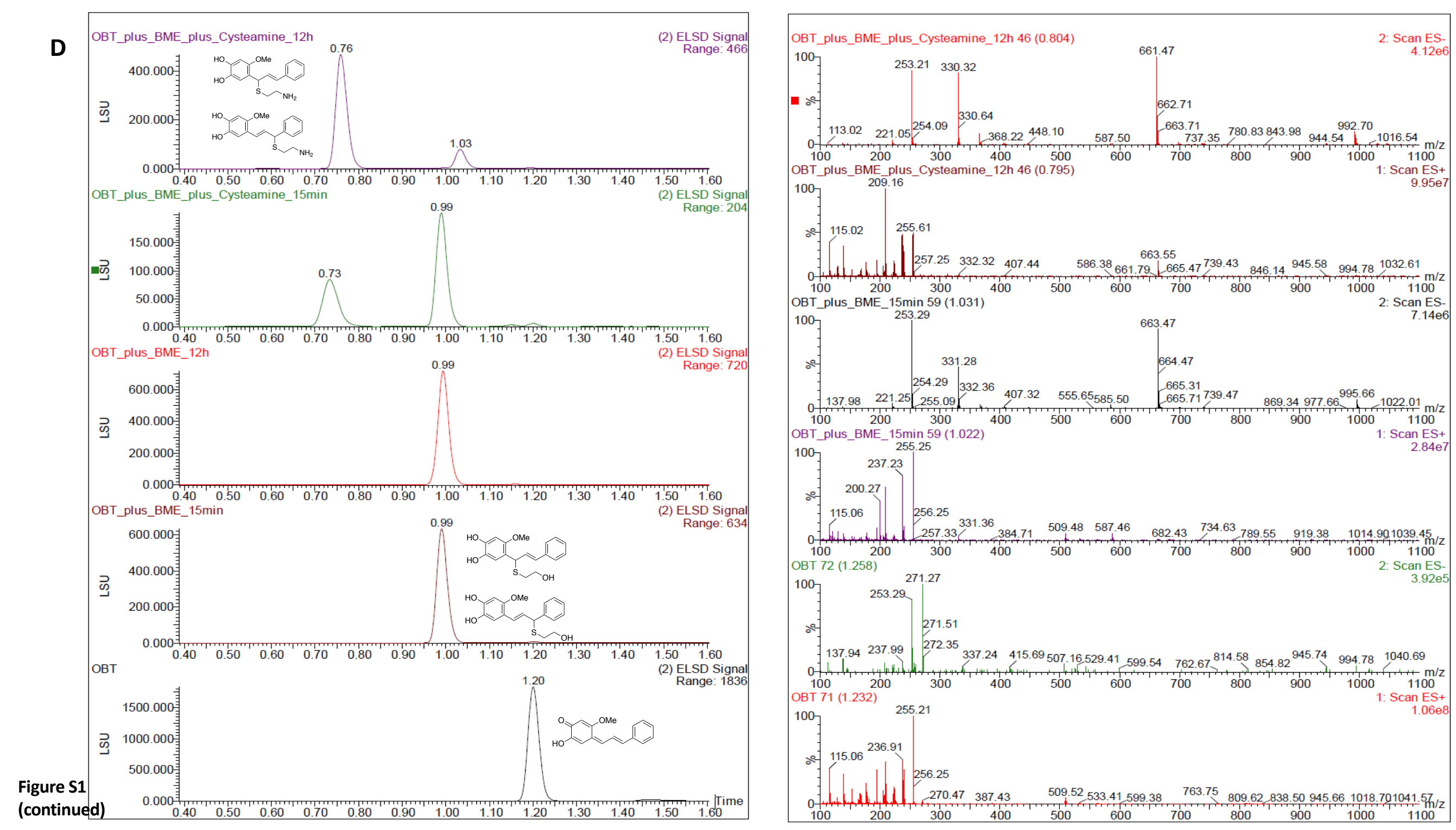
A

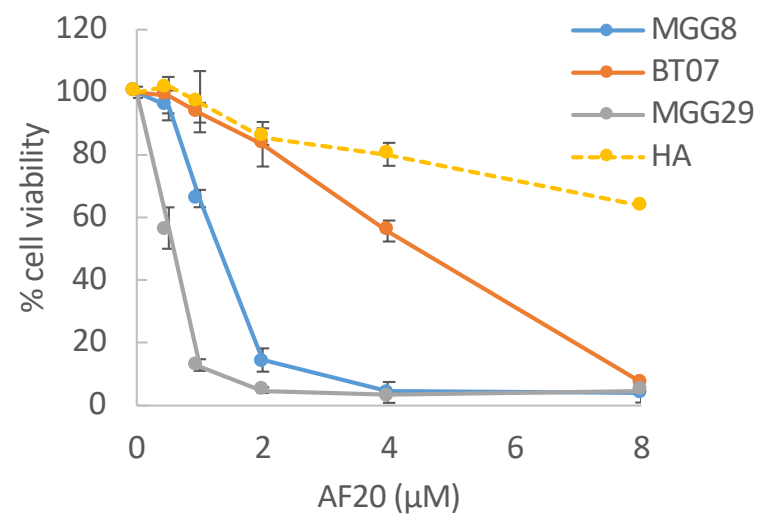

B

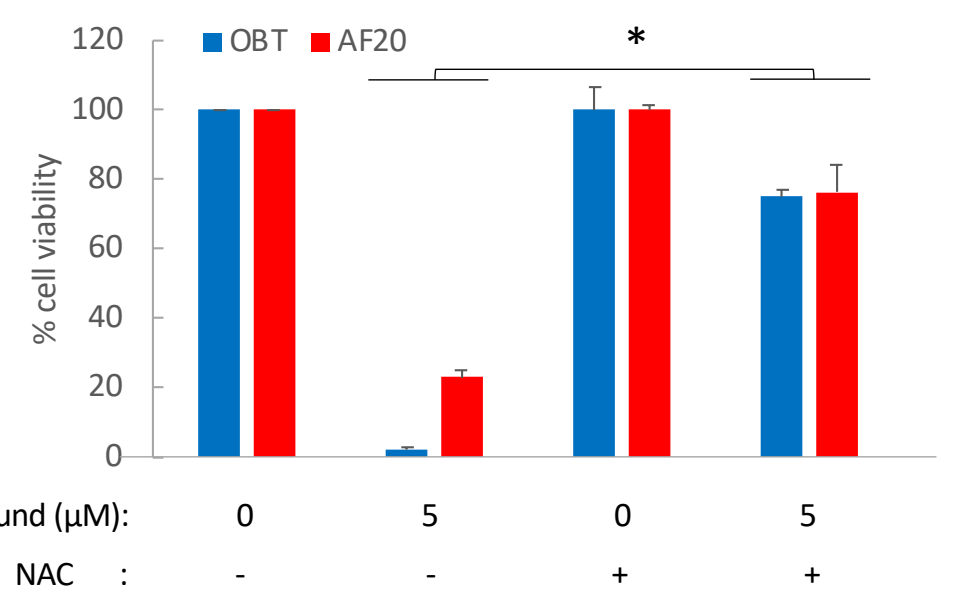

C

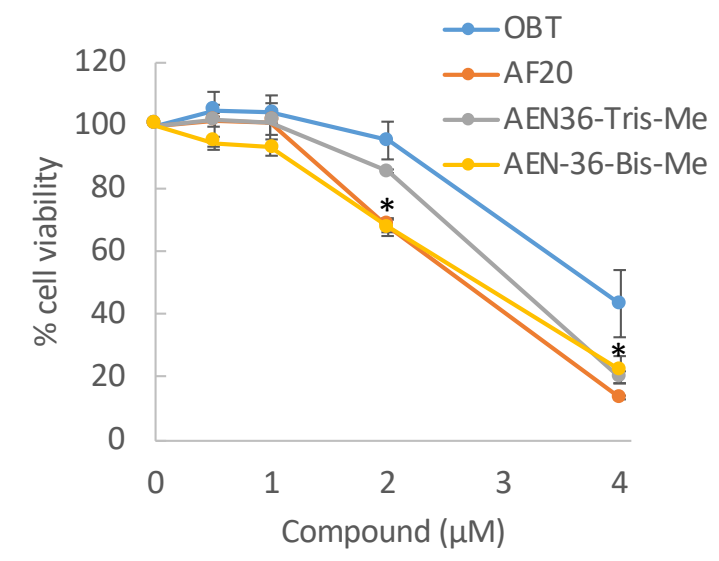

D

\section{Bovine Catalase}

MADNRDPASDQMKHWKEQRAAQKPDVLTTGGGNPVGDKLNSLTVGPRGPLLVQDVVFTDEMAHFDRERIPERVVHAKGAG AFGYFEVTHDITRYSKAKVFEHIGKRTPIAVRFSTVAGESGSADTVRDPRGFAVKFYTEDGNWDLVGNNTPIFFIRDALI FPSF IHSQKRNPQTHLKDPDMVWDFWSLRPES LHQVSFLFSDRG I PDGHRHMNGYGSHTFKLVNANGEAVYC (232) KFH YKTDQGIKNLSVEDAARLAHEDPDYGLRDLFNAIATGNYPSWTLYIQVMTFSEAEIFPFNPFDLTKVWPHGDYPLIPVGK LVLNRNPVNYFAEVEQLAFDPSNMPPGIEPSPDKMLQGRLFAYPDTHRHRLGPNYLQI PVNC (377) PYRARVANYORDG PMCMMDNQGGA PNYYPNSFSAPEHQPSALEHRTHFSGDVQRFNSANDDNVTQVRTFYLKVLNEEQRKRLC (460) ENIAG HLKDAQLFIQKKAVKNFSDVHPEYGSRIQALLDKYNEEKPKNAVHTYVQHGSHLSAREKANL

\section{Figure S2}


A

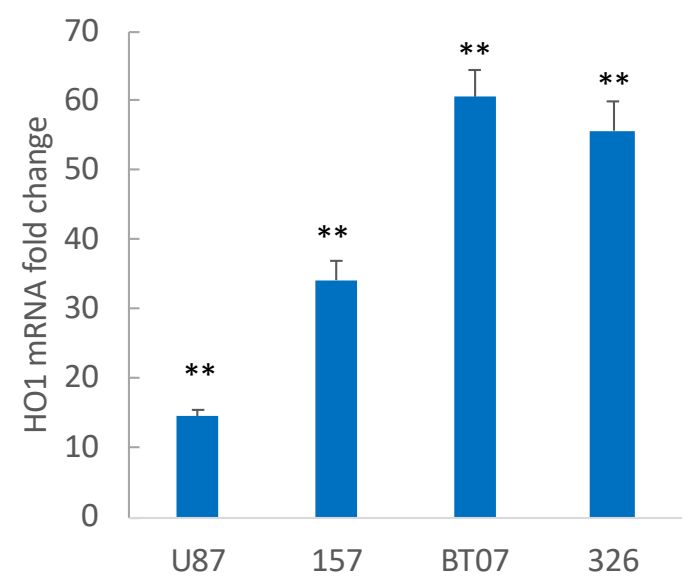

C

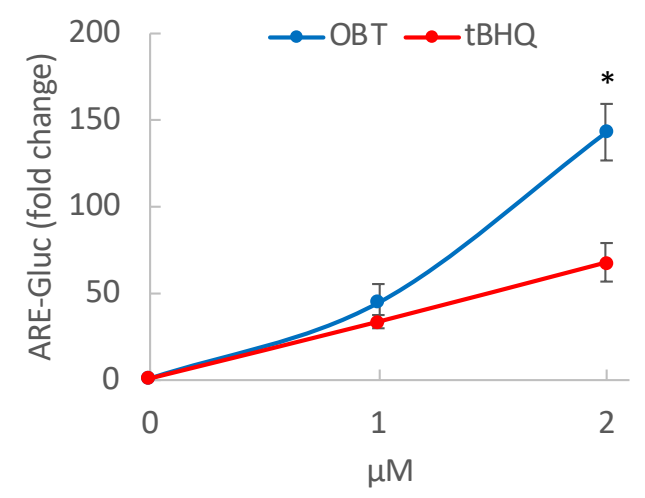

B

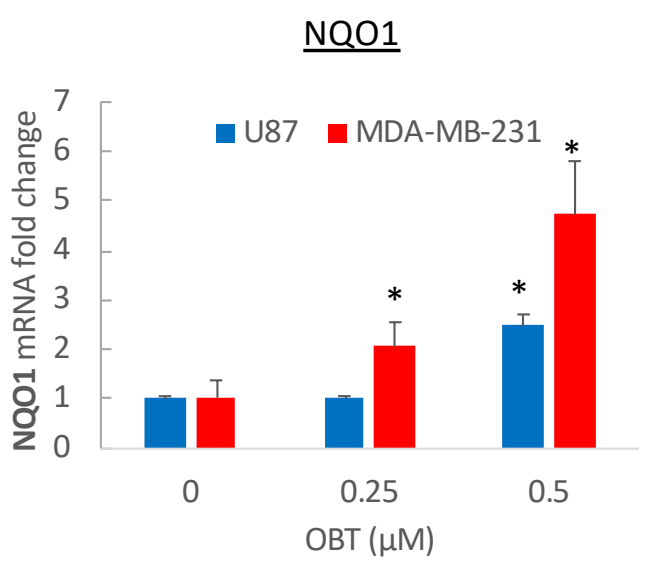

$\underline{\text { U87 }}$

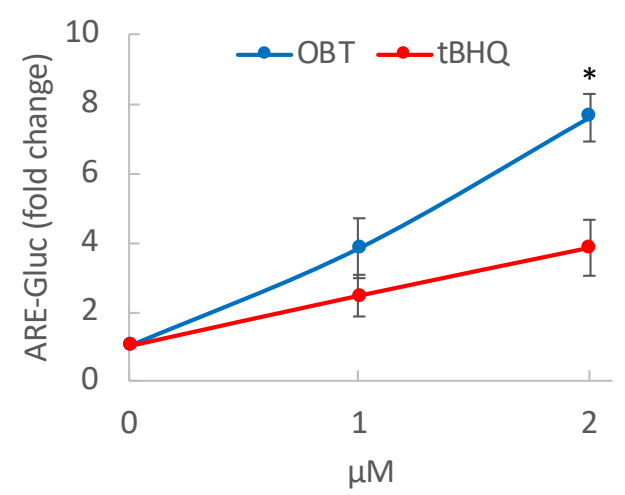

E $\underline{\text { Txnrd2 }}$
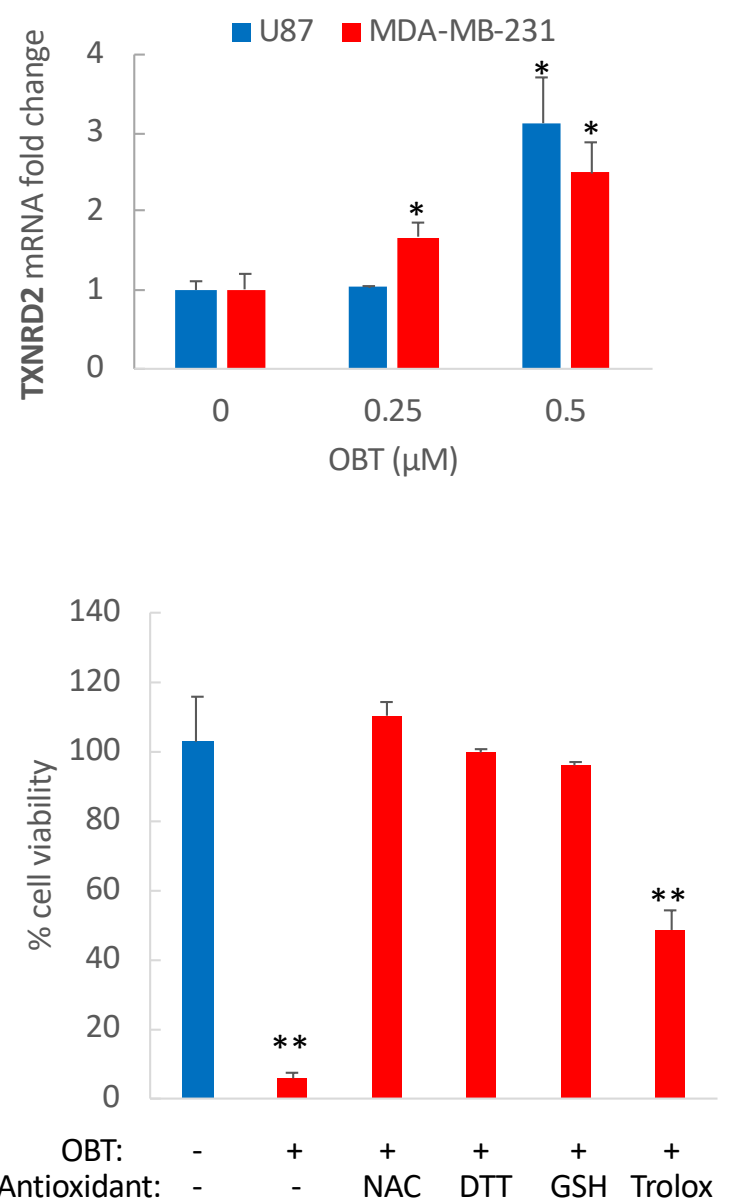

Figure S3 


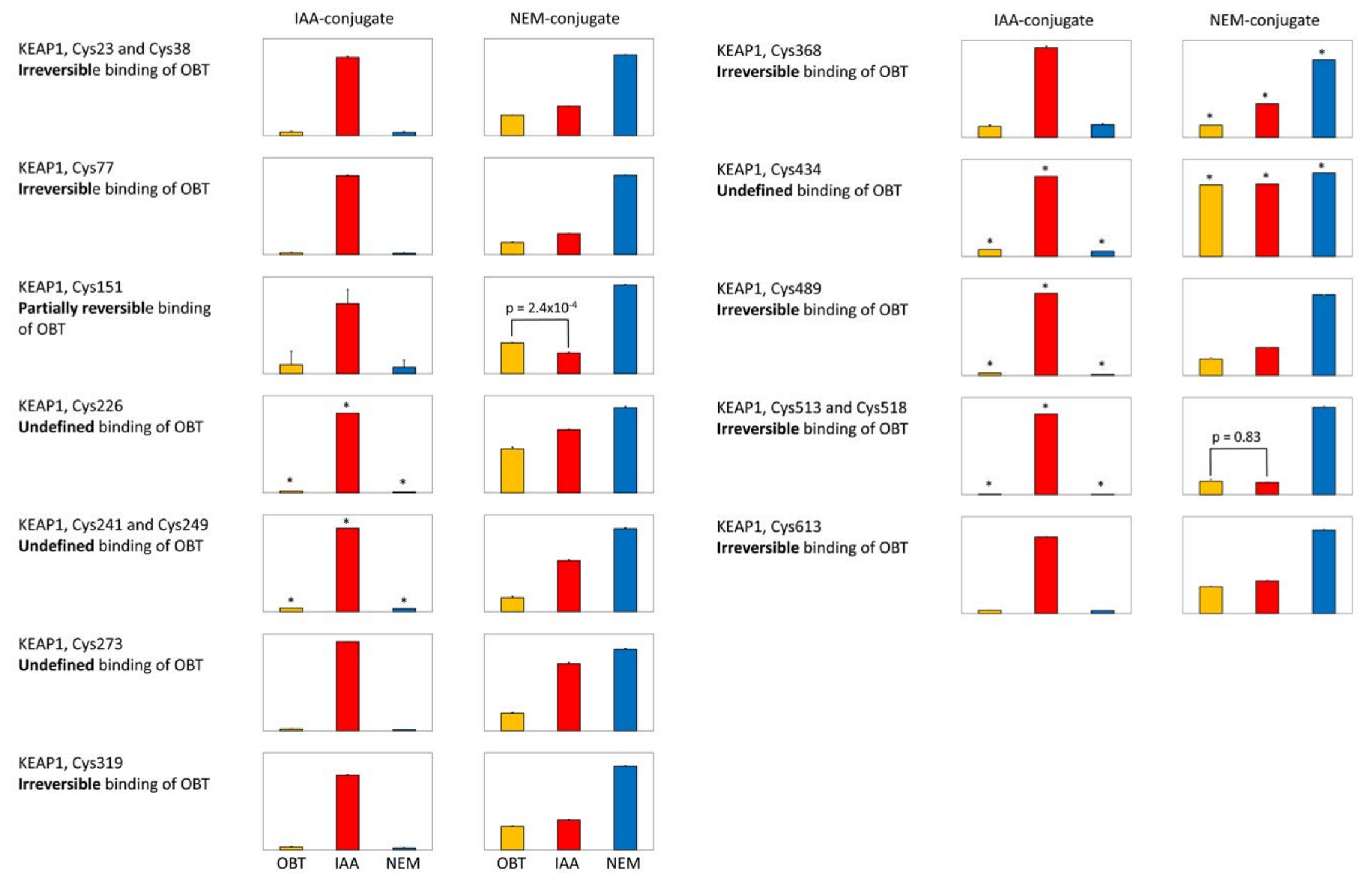


A

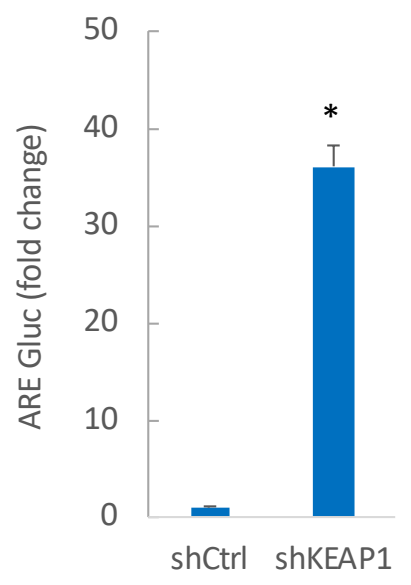

c

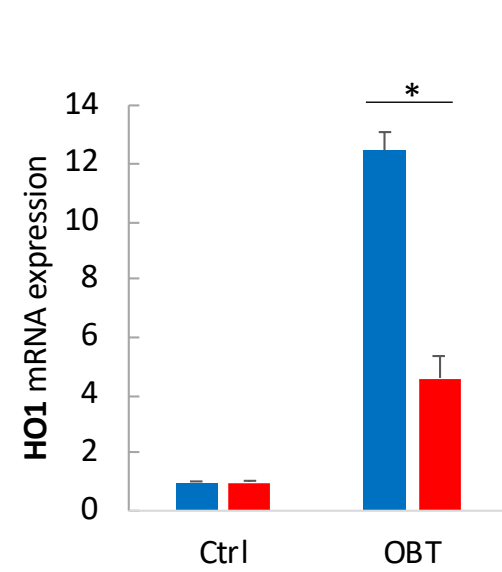

NQ01

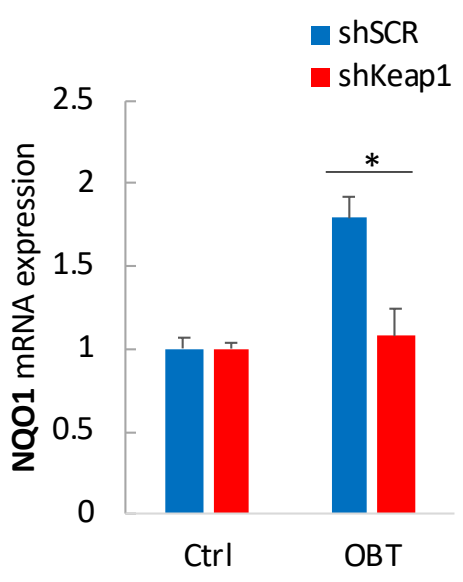

B

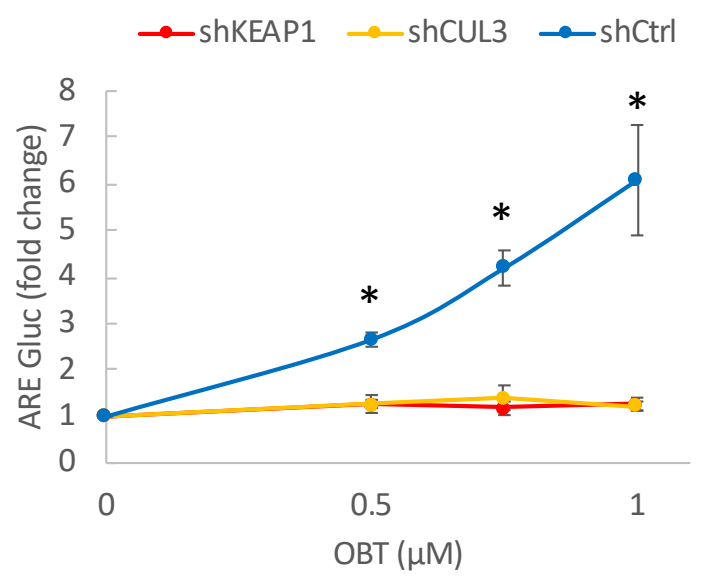

D

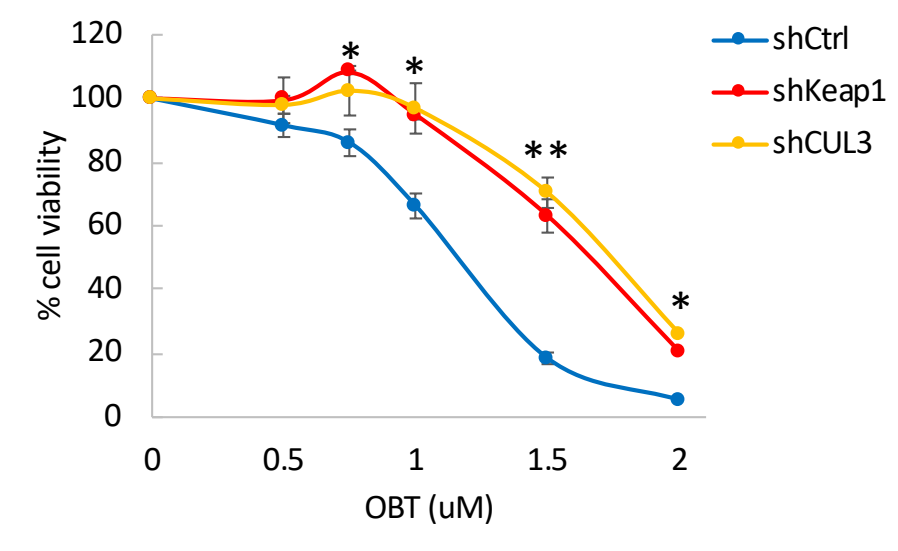

Figure S5 
A

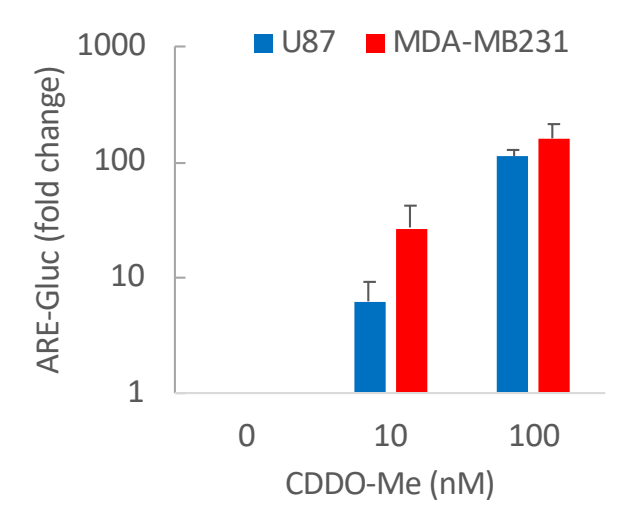

D

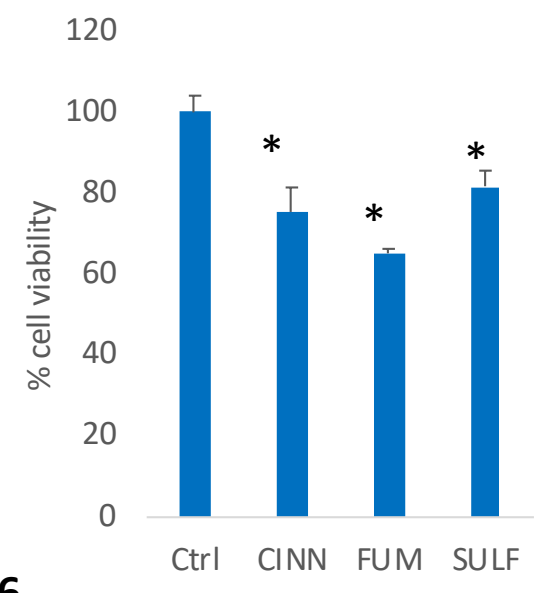

B

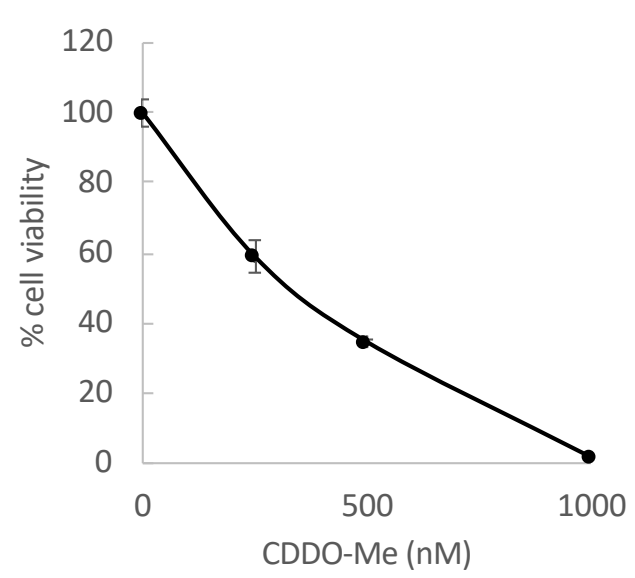

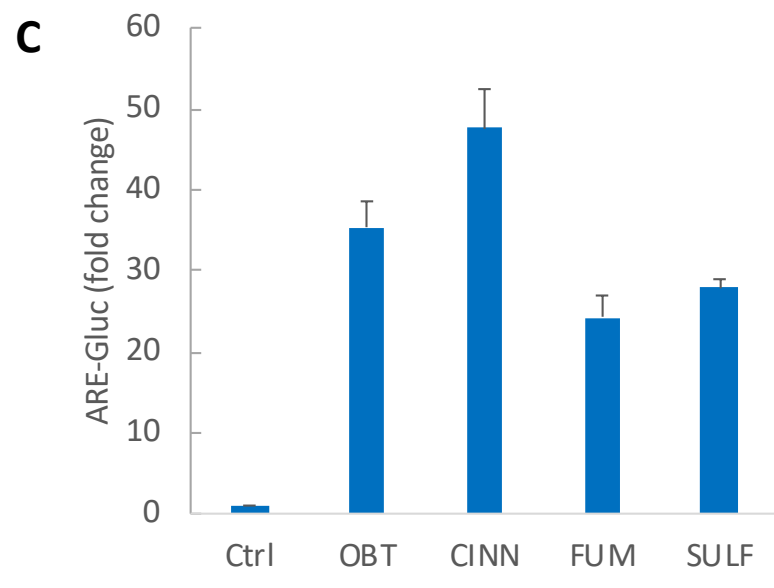

Figure S6

E

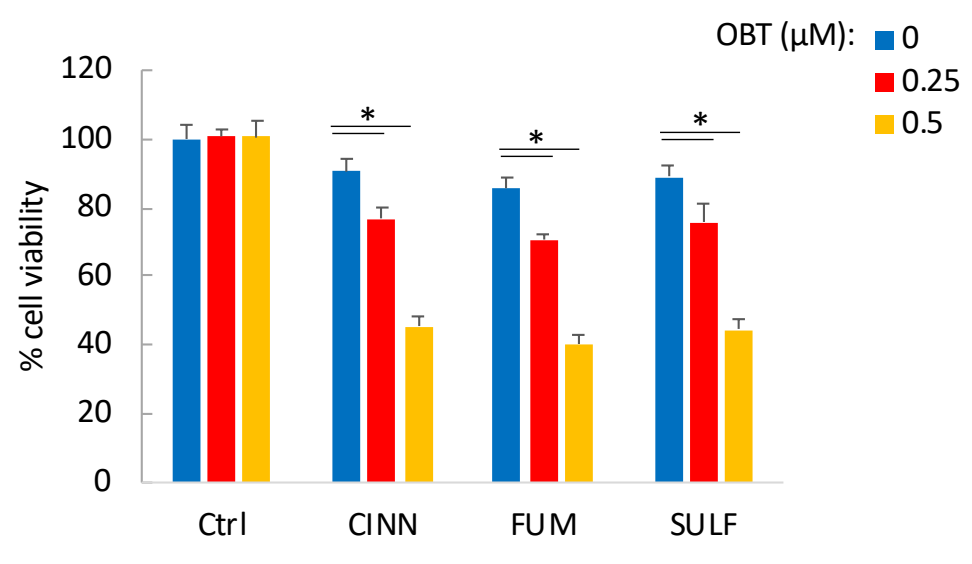


A

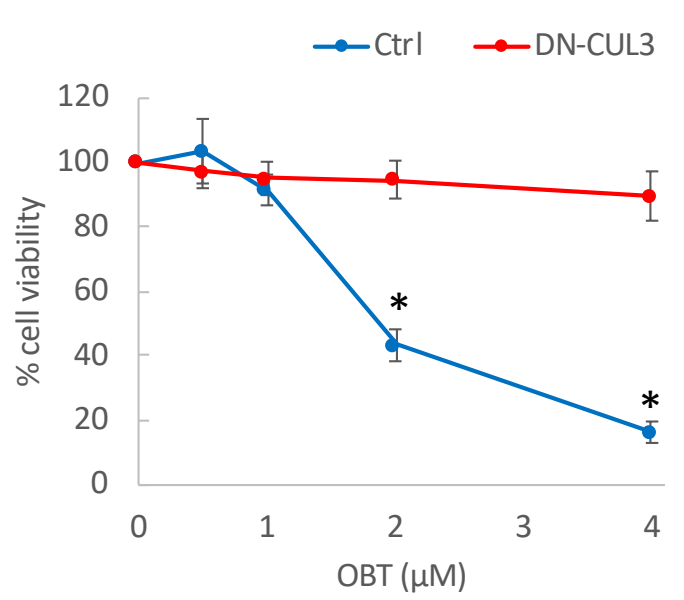

B

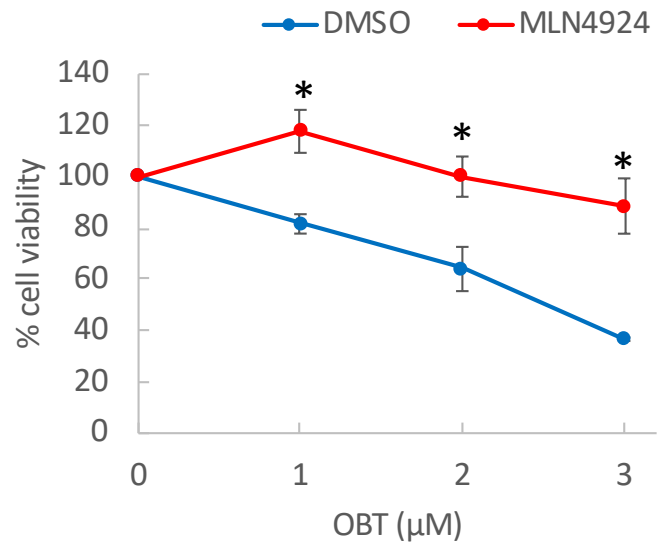

C

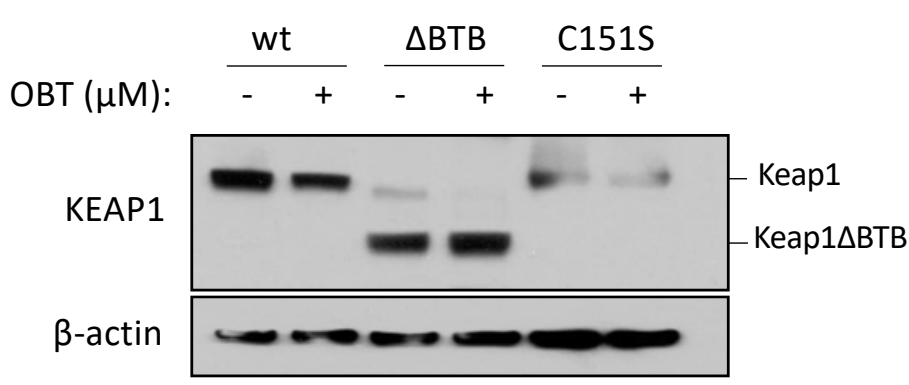

\section{Figure S7}


A

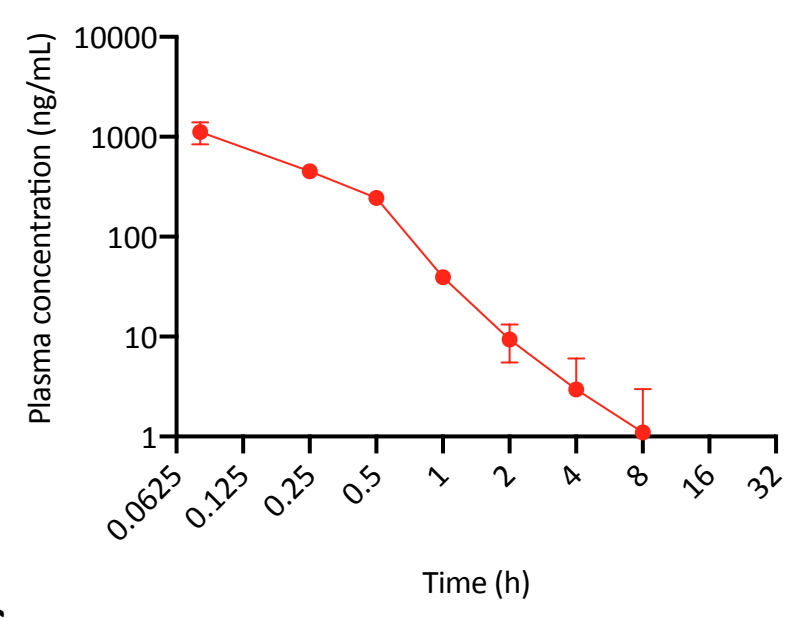

C

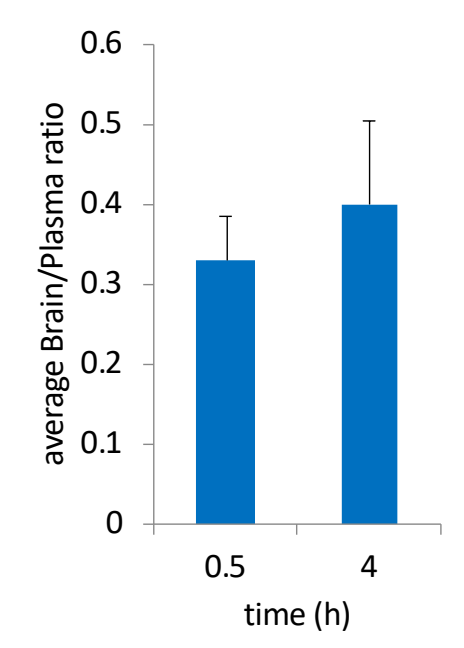

Figure S8
B

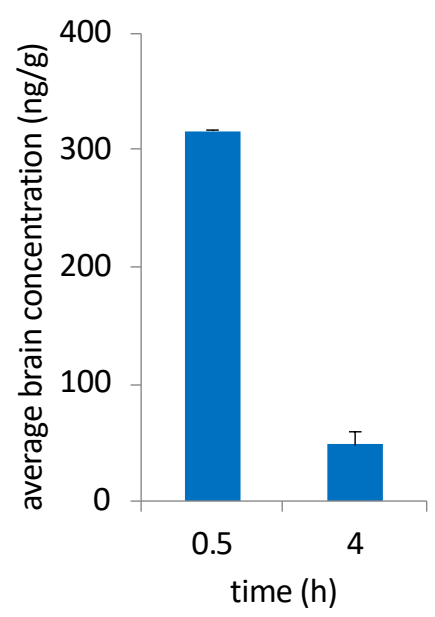

\section{D}

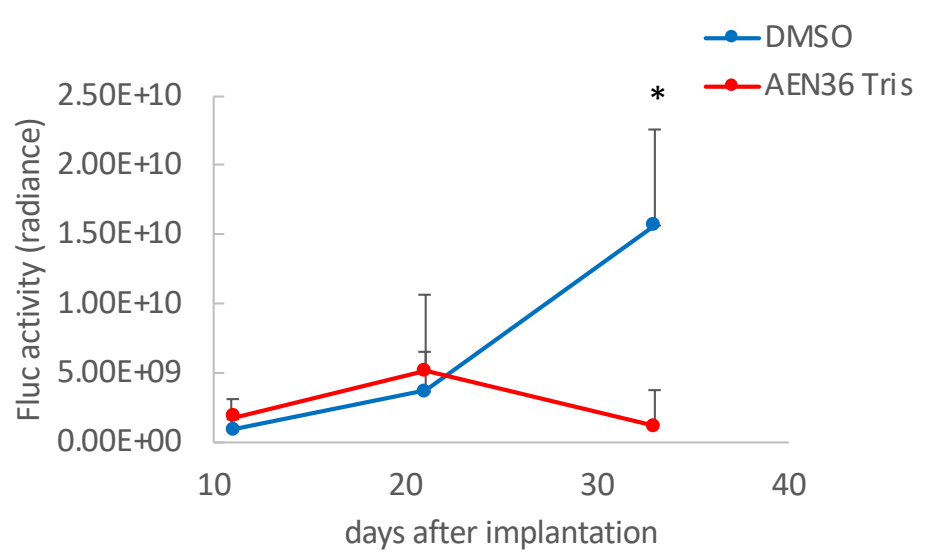




\section{SUPPLEMENTAL FIGURE LEGENDS}

Supplemental Figure 1: Reactivity of OBT and analogs. (A) OBT features a hydroxy paraquinone methide (red), which readily reacts with nucleophiles (blue) under the formation of catechols. (B) Glutathione (GSH) reacts with the quinone methide SI1 under the formation of two distinct diastereomeric pair derived from direct (SI2a, SI2b) and vinylogous (SI3a, SI3b) addition. (C) OBT reacts with beta-mercaptoethanol (BME) forming the products derived from direct (AF20a) and vinylogous (AF20b) addition to the quinone-methide core (individual enantiomers are not shown). Addition of excess cystamine to AF20 results in displacement of BME and the formation of SI4a and SI4b. (D) LC/MS traces which show chromatographic separation with baseline separated peaks thus allowing to unambiguously identify and quantify the BME and cystamine adducts of OBT.

Supplemental Figure 2: Efficacy of OBT analogs. (A) Different GSCs (MGG8; BT07 and MGG29) and normal human astrocytes (HA) were treated with AF20 at the indicated doses. Cell viability was measured four days after treatment and expressed as percentage of control. (B) U87 glioma cells were treated with OBT or AF20 in the presence or absence of NAC ( $3 \mathrm{mM})$ and cell viability was measured $48 \mathrm{~h}$ later. (C) U87 cells were treated with different doses of OBT or analogs and cell viability was measured four days later and expressed as percentage of vehicle control; ${ }^{*} \mathrm{P}<0.05$ Student $t$ test; statistical significance depicts the difference in cell viability between OBT and its analogs. (D) Amino acid sequence of the bovine catalase indicating in red the cysteine residue modified by OBT.

Supplemental Figure 3: OBT induces Nrf2 activation. (A) HO1 mRNA expression levels determined by qRT-PCR and normalized to GAPDH in U87 cells and 3 different GSCs (157; BT12; 326) treated with OBT $(1 \mu \mathrm{M})$ for 8 hours. (B) NQO1 and Txnrd2 mRNA levels in U87 and MDA-MB-231 cells after treatment with different doses of OBT. (C-D) MDA-MB-231 (C) and U87 
cells (D) expressing the ARE-Gluc and SV40-Vluc reporters were treated with OBT or tBHQ. Aliquots of the conditioned medium were assayed for Gluc and Vluc activity. Data presented as a ratio of Gluc/Vluc and normalized to vehicle control (set at 1). (E) U87 cells were treated with DMSO (control) or OBT $(1 \mu \mathrm{M})$ and different antioxidants. Cell viability was measured four days later. Data expressed as percentage of cell viability normalized to the control, showing that DTT and GSH completely rescued OBT-mediated cell death, whereas Trolox provided a partial rescue. Statistical significance depicts the difference between the samples treated with OBT alone as compared to the combination of OBT with the antioxidants. ${ }^{*} \mathrm{P}<0.05$; ${ }^{* *} \mathrm{P}<0.001$ Student $t$ test.

\section{Supplemental Figure 4. Mapping of OBT covalent biding to cysteine residues in Keap1.} Differential alkylation patterns for Keap1 cysteine containing peptides (see Supplemental Table 4). Interpretation guidance of the patterns is given in Figure 1E. The IAA-conjugate pattern defines if OBT is binding to the indicated cysteine-residue; OBT is binding to all twelve quantified cysteines. The NEM-pattern is defining the nature of the OBT binding. We observed three different categories: irreversible binding, with OBT and IAA channels at an intensity at least 2-fold lower than the NEM channel, and the OBT channel not being significantly $(p \leq 0.01$, see Supplemental Table 4) higher than the IAA channel intensity; partially reversible binding, as irreversible binding but with an OBT channel intensity significantly higher than the IAA intensity; undefined binding, the IAA channel intensity is at least as high as the NEM channel intensity.

\section{Supplemental Figure 5: OBT targets Keap1 and activates Nrf2 pathway. (A) MDA-MB231}

cells expressing ARE-Gluc and SV40-Vluc reporters were transduced with shCtrl or shKeap1. Four days later, aliquots of the conditioned medium were assayed for Gluc and Vluc activity. The data is expressed as the ratio of Gluc/Vluc, normalized to vehicle control (set at 1). (B) ARE-Gluc activity normalized to SV40-Vluc in MDA-MB231 expressing shCtrl, shKeap1 or shCUL3 after treatment with different doses of OBT. (C) HO1 and NQO1 mRNA expression determined in U87 
cells expressing either shCtrl or shKeap1 following 8 hrs of OBT treatment. (D) MDA-MB231 cells stably expressing shCtrl, shKeap1 or shCUL3 were treated with different doses of OBT and cell viability was measured after four days. ${ }^{*} \mathrm{P}<0.05 ;{ }^{* *} \mathrm{P}<0.001$ Student $t$ test.

Supplemental Figure 6: (A) U87 and MDA-MB231 cells expressing ARE-Gluc and SV40-Vluc reporters were treated with CDDO-Me at the indicated doses. Aliquots of the conditioned medium were assayed for Gluc and Vluc activity. Data expressed as the ratio of Gluc/Vluc, normalized to vehicle control (set at 1). (B) Cell viability of MDA-MB231 cells after 3 days of treatment with CDDO-Me. (C) ARE-Gluc activity normalized to SV40-Vluc in U87 cells treated with OBT (1 $\mu \mathrm{M})$, Cinnamaldehyde (CINN, $100 \mu \mathrm{M})$, diethyl fumarate (FUM, 50uM) or sulforaphane (SULF, $5 \mu M)$. (D) Cell viability in U87 cells treated with CINN, FUM or SULF (same doses as in C). (E) U87 cells were co-treated with OBT (at the indicated doses) and either CINN, FUM or SULF (same doses as in C). Cell viability was determined after three days of treatment. ${ }^{*} P<0.05$ Student $t$ test

Supplemental Figure 7: (A) MDA-MB231 cells expressing an empty vector (Ctrl) or dominant negative CUL3 (DN-CUL3) were treated with OBT before measuring cell viability after 3 days. (B) MDA-MB231 cells were co-treated with OBT and DMSO (control) or MLN4924 $(1 \mu \mathrm{M})$ and cell viability was measured three days later. (C) MDA-MB231 cells were transfected with Keap1 wildtype (wt), Keap1 $\triangle \mathrm{BTB}$ or Keap1C151S, and co-treated with $\mathrm{CHX}(3 \mu \mathrm{g} / \mathrm{mL})$ and OBT (4 $\mu \mathrm{M})$ or vehicle control. Cell lysates were collected after 8 hours and immunoprecipitation was performed using anti-HA antibody followed by immunoblotting for Keap1 and HA. * $\mathrm{P}<0.05$ Student $t$ test

\section{Supplemental Figure 8: Pharmacokinetics analysis of OBT. (A) Average plasma} concentration-time profiles of OBT following a single intraperitoneal administration (i.p.; 7.5 $\mathrm{mg} / \mathrm{kg}$ ) in male Swiss Albino mice. Data analyzed by LC-MS/MS. Plasma concentrations were detected up to $24 \mathrm{hrs}$ with Tmax of $0.5 \mathrm{hr}$. The Vss was 3-fold higher than the normal volume of 
total body water $(0.7 \mathrm{~L} / \mathrm{kg})$ indicating extravascular distribution. (B-C) Average brain concentration (B) and brain/plasma ratio (C) at 0.5 or 4 hours following a single i.p. administration of OBT. The brain-to-plasma ratios ranged from 0.27 to 0.5 at $0.5 \mathrm{hr}$ and $4 \mathrm{hrs}$ respectively. (D) Mice-bearing fat pad MDA-MB231 tumors expressing Fluc were treated with either DMSO vehicle control $(n=5)$ or AEN36 Tris $(10 \mathrm{mg} / \mathrm{kg})$ daily over 22 days. At different time points, tumor volume was monitored by Fluc bioluminescence imaging, and tumor-associated photons were calculated and presented as the average radiance $\pm \mathrm{SD}$. ${ }^{*} \mathrm{P}<0.05$ Student $t$ test.

\section{SUPPLEMENTAL TABLE LEGENDS}

Supplemental Table 1: Bovine catalase peptides quantified in differential alkylation experiment (Fig 1 C-F).

z: peptide ion charge.

XCorr. primary score of the SEQUEST database search algorithm used to annotate the MS2 spectra.

$d C n$ : the secondary score of the SEQUEST algorithm; the relative difference $(0-1)$ between the XCorr of the best match for the MS2 spectra and that of the second-best unique peptide sequence.

Mass deviation: deviation of the measured intact peptide mass relative to the predicted mass (the deviation is calculated after re-calibrating the acquired data based on high-confidence MS2 annotations);

LDA_probablility: The probability of an incorrect peptide annotation calculated using a posterior error histogram from sorting peptide annotations from the forward and the reversed database based on their LDA score.

Normalized Intensities (OBT1-3, IAA1-3, NEM1-3): A two-tiered normalization was performed upon extracting TMT reporter ion intensities form the MS3 spectra. First, an average intensity was calculated for each peptide across all nine channels (OBT1-NEM3) and the peptide intensity 
was normalized using the median average value across all peptides as reference. In a second normalization step, the median intensity for all non-cysteine-containing peptides was calculated for each of the nine channels and used for normalization of all peptides (cysteine-containing and non-cysteine-containing) using the average of all nine median values as a reference. Unmarked cysteine residues in the peptide sequences were identified as being alkylated with iodoacetamide (IAA), those marked with a number sign (\#) were identified as being alkylated with NEM.

Supplemental Table 2: Cysteine containing catalase peptides quantified both with IAA and NEM thiol alkylation in a differential alkylation experiment (Fig. 1F). Reporter ions were combined through summation, if peptides including the listed cysteines were quantified more than once in the experiment (see Supplemental Table 1). Average, standard deviation, and p-values (student's t-test, two-tailed, unequal variances) were determined across the three measurements performed for each alkylation protocol (OBT, IAA, NEM).

Supplemental Table 3. Quantitative mass spectrometry-based proteomics using 10-plexed tandem mass tags (TMT) to simultaneously map protein concentration changes of 7,904 proteins in two GSCs, GBM8 and BT07, either untreated (duplicates) or treated with OBT (triplicates) for 20 hours.

Supplemental Table 4. Keap1 peptides quantified in differential alkylation experiment (see Supplemental Table 1 for detailed description of column headers).

Supplemental Table 5. Cysteine containing Keap1 peptides quantified both with IAA and NEM thiol alkylation in in differential alkylation experiment (Fig. 2G and Supplemental Fig. 1). One sample was analyzed for each alkylation protocol (OBT, IAA, NEM) and average, standard deviation, and p-values (student's t-test, two-tailed, unequal variances) were determined for all 
peptides carrying the indicated cysteine residue. If the measurement was done based on only one peptide, the indicated average value is the measured intensity.

\section{SUPPLEMENTAL METHODS}

\section{DNA expression constructs}

ARE reporter was designed and generated based on our previously published reporter for monitoring of the transcription factor Nuclear Factor Kappa B (NFkB) ${ }^{1}$. NFkB TRE elements were removed and replaced with four copies of the ARE enhancer sequence. This reporter consists of a CSCW lentivirus vector in which we have introduced two copies of the $1.2 \mathrm{~kb}$ chicken betaglobin (HS4) insulator elements, a TATA box acting as a minimal promoter upstream of the secreted Gaussia luciferase (Gluc). pcDNA3-HA2-Keap1 (Addgene plasmid \# 21556) and pcDNA3-HA2-Keap1 delta BTB (Addgene plasmid \# 21593) were a gift from Yue Xiong². pHAGE DN Cullin 3 (DN-CUL3) was a gift from Stephen Elledge (Addgene plasmid \# 41913). Constructs expressing constitutively active Gluc, Firefly luciferase (Fluc) and Vargula luciferase (Vluc) were previously described ${ }^{1,3,4}$. MISSION shRNA Bacterial Glycerol Stocks for Keap1 as well as a nontarget shRNA were obtained from Sigma. Transfection of plasmid DNA was performed using Lipofectamine 2000 (Invitrogen) as per manufacturer's guidelines. Lentivirus packaging and titration was performed in $293 \mathrm{~T}$ cells by the $\mathrm{MGH}$ viral vector core facility following standard protocols. Keap1 mutant C151S plasmid was kindly provided by Dr. Wooyoung Hur.

\section{Luciferase assay}

Coelenterazine $(20 \mu \mathrm{M}$; Nanolight), The Gluc substrate was added to a $25 \mu \mathrm{L}$ aliquot of conditioned medium and photon counts were measured using a luminometer. Similarly, the secreted Vluc activity was measured by adding its substrate vargulin (5ng/mL; Nanolight). Cells stably expressing Gluc under the ARE enhancer sequence and Vluc under the constitutively 
active SV40 minimal promoter were used to determine the ARE reporter activity. The normalized Gluc/Vluc ratio was used as a marker for ARE activation.

\section{Pharmacokinetics studies}

These studies were performed by SAI Lifesciences using Male Swiss Albino mice. OBT was resuspended in a solution formulation of $10 \% \mathrm{DMA}, 10 \% \mathrm{EtOH}, 10 \% \mathrm{PEG} 400$ in $70 \%$ of (2-

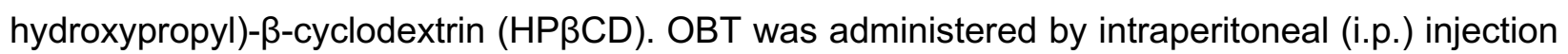
at $7.5 \mathrm{mg} / \mathrm{kg}$. Blood samples were collected from mice, at $0,0.08,0.25,0.5,1,2,4,8$ and $24 \mathrm{hr}$. Immediately after blood collection, plasma was harvested by centrifugation and stored until analysis. After collection of blood, brain samples were collected from each mouse at $0.5,4$ and

$24 \mathrm{~h}$. Tissue samples were homogenized using ice-cold phosphate buffer saline $(\mathrm{pH} 7.4)$ and homogenates were stored until analysis. Total homogenate volume was three times the tissue weight. Plasma samples were quantified by LC-MS/MS method $(\mathrm{LLOQ}=1.00 \mathrm{ng} / \mathrm{mL})$ for plasma and brain.

\section{Immunoblotting and Immunoprecipitation analysis}

Antibodies against PDI, GAPDH, HA-tag, Ubiquitin, Keap1 and beta-actin (Cell Signaling) as well as secondary Horseradish peroxidase (HRP) conjugated antibodies: sheep anti-mouse lgG-HRP and donkey antirabbit IgG-HRP (Amersham Pharmacia Biotech) were used in this study. For protein expression analysis, cells were lysed in RIPA buffer (150 mM NaCl, 50 mM TRIS, pH 8.0, $1 \%$ NP-40, 0.5\% deoxycholate, $0.1 \%$ SDS) supplemented with $1 x$ protease inhibitors cocktail (Roche). Proteins were quantified using a Bradford protein determination assay (Bio-Rad) followed by electrophoresis in 10\% NuPAGE Bis-Tris gels (Life Technologies) and transfer to nitrocellulose membranes (Bio-Rad). Membranes were incubated overnight with antibodies in 1$5 \%$ non-fat milk powder in PBS/0.5\%TWEEN. Proteins were detected with SuperSignal West Pico Chemiluminescent Substrate (Pierce). For immunoprecipitation assays, cells were lysed in RIPA 
buffer supplemented with protease inhibitors and $2 \mathrm{mM} \mathrm{N}$-ethylmaleimide. Cell lysates were precleared with protein A agarose beads (Cell Signaling) and incubated with anti-HA antibody with gentle rocking overnight at $4^{\circ} \mathrm{C}$ followed by incubation with protein $\mathrm{A}$ agarose beads and subsequent washing and elution steps. Electrophoresis, transfer and immunoblot analysis was performed as described above.

\section{Real-time qRT-PCR}

Total RNA isolation from cultured cells was performed using RNeasy kit (Qiagen), followed by reverse transcription with OneScript cDNA synthesis Kit (ABM). mRNA expression of different genes was then analyzed by quantitative PCR using PowerUp SYBR Green Master Mix (Applied Biosystems) and performed using a QuantStudio3 real-time PCR system (Applied Biosystems). Primer sequences for HO1, NQO1, TXNRD2 were obtained from the MGH primer bank and were as follows: HO1 Forward, 5'-AAGACTGCGTTCCTGCTCAAC-3' and reverse 5'AAAGCCCTACAGCAACTGTCG-3' ; NQO1 Forward 5'-GAAGAGCACTGATCGTACTGGC-3' and reverse 5'-GGATACTGAAAGTTCGCAGGG-3' and Txnrd2 forward 5'CTAGCCCCGACACTCAGAAGA-3 and reverse 5'-GGCCATGATCGCTATGGGT.

Oligonucleotides were synthesized by the CCIB DNA Core Facility at Massachusetts General Hospital. Expression of human GAPDH was used to mRNA normalization and relative mRNA expression was calculated using the comparative Ct method.

\section{In vivo Tumor Models}

Animal experiments performed by our laboratory were approved by the Massachusetts General Hospital Subcommittee on Research Animal Care. Female athymic nude mice (6-8 weeks) were used in all studies with the exception of pharmacokinetics analysis. For brain tumors xenograft model, GBM8 cells $\left(1 \times 10^{5}\right.$ cells/mouse) stably expressing Fluc were stereotactically implanted 
into the left striatum of animals. Following implantation, animals were regularly imaged for Fluc to monitor brain tumor growth. To generate the breast cancer model, MDA-MB-231 cells $\left(2.5 \times 10^{5}\right.$ cells/mouse) expressing Fluc were mixed with Matrigel 1:1 (v/v) (BD Matrigel) and injected into the mammary fat pad of mice. Tris-OBT was dissolved in PBS and administered intraperitoneally. Tumor volumes were measured using a caliper and calculated according to the following formula:

volume $=(\text { width })^{2} \times$ length/2. For Fluc bioluminescence imaging, Fluc substrate, $\mathrm{D}$-luciferin (Gold Biotechnology) (150mg/kg body weight diluted in PBS) was injected i.p. and animals were imaged using an IVIS Spectrum optical imaging system (Caliper Life Sciences) under isofluorane gas anesthesia.

\section{FDG-PET imaging}

Mouse PET/CT scans ( $n=6,3$ per group) were performed sequentially using a custom-designed mouse bed and PET/CT gantry adapter. Mice were injected intravenously through the tail vein with approximately $600 \mathrm{uCi}$ of fluorodeoxyglucose (F-18-FDG) and imaged on the Inveon small animal imaging system (Siemens Healthcare, Malvern, PA) for positron emission computed tomography and computed tomography (PET-CT) $\sim 45$ minutes after injection. Isovue 370 (Bracco Diagnostics, East Princeton, NJ) CT contrast was administered through a tail vein catheter at a rate of $10 \mathrm{ul} / \mathrm{min}$ for the duration of the $10 \mathrm{~min}$ CT scan for a total volume of $200 \mathrm{ul}$ per mouse, prior to the acquisition of PET images. CT images were acquired over 360 projection with a 500 uA $80 \mathrm{kVp}$ cone beam x-ray tube and a flat panel CMOS detector and reconstructed with a modified Feldkamp cone beam reconstruction algorithm (COBRA) (Exxim Computing Company, Pleasanton, CA) into a 110 micron isotropic voxel matrix. The PET scan was acquired over 30 minutes and reconstructed by filtered back projection with Fourier rebinning and a ramp filter with a Nyquist cutoff frequency of 0.5 .

The contrast-enhanced CT images were used to identify the location of the tumor and delineate 
its margins as regions-of-interest (ROI). The same ROls are then copied to the matching PET images for quantification of the ${ }^{18}$ F-FDG PET signal as the standard uptake values (SUVs). The SUVS of the tumor are then divided by the SUVs of muscle for each mouse to normalize differences between animals.

\section{Medicinal Chemistry}

Obtusaquinone was purchased from Gaia Chemical Corporation. Absolute ethanol (anhydrous) was purchased from Decon Laboratories. $\beta$-mercaptoethanol, acetic anhydride, and pyridine were purchased from Sigma-Aldrich. All chemicals and solvents were used without further purification unless otherwise noted.

Thin layer chromatography was performed with precoated aluminum-backed TLC plates (Silica XG Plates, w/UV254, 200 uM, 20x20 cm) obtained from Sorbtech Sorbent Technologies. Visualization of TLC plates was performed with a UVGL-25 Compact UV Lamp (4 watt, 254/365 nm, $115 \mathrm{~V} \sim 60 \mathrm{~Hz} / 0.16$ Amps).

Flash column chromatography was performed on a Biotage Isolera Four Flash Purification System equipped with a 200-400 nm diode array detector using Sorbtech Sorbent Technologies Purity Flash Cartridges (Spherical Silica Gel 12 g, 20-45 uM, 70 A).

Purity of compounds was determined by analytical LC-ELSD-MS performed on a Waters 2545 HPLC equipped with a 2998 diode array detector and a Waters 3100 ESI-MS module, using a XTerraMS C18 $5 \mu \mathrm{m}, 4.6 \times 50 \mathrm{~mm}$ column at a flow rate of $5 \mathrm{~mL} / \mathrm{min}$ with a linear gradient $(95 \%$ $A / 5 \% B \rightarrow 100 \% B$ with $90 \mathrm{~s}$ and $30 \mathrm{~s}$ hold at $100 \% \mathrm{~B}$, solvent $A=$ water $+0.1 \%$ formic acid, solvent $B=$ acetonitrile $+0.1 \%$ formic acid)

${ }^{1} \mathrm{H}$ and ${ }^{13} \mathrm{C}$ NMR spectra were recorded on a Bruker Ascend ${ }^{\mathrm{TM}}$ spectrometer at 400 and $100 \mathrm{MHz}$, respectively. Chemical shifts for protons are reported in parts per million (ppm) and are referenced to residual solvent peaks for $\mathrm{CHCl}_{3}(7.26 \mathrm{ppm})$. Data is reported as follows: chemical shift, 
multiplicity ( $\mathrm{s}=$ singlet, $\mathrm{d}=$ doublet, $\mathrm{t}=$ triplet, $\mathrm{q}=$ quadruplet, $\mathrm{m}=$ multiplet, $\mathrm{br}=$ broad $)$, coupling constants $(\mathrm{Hz})$, and integration.
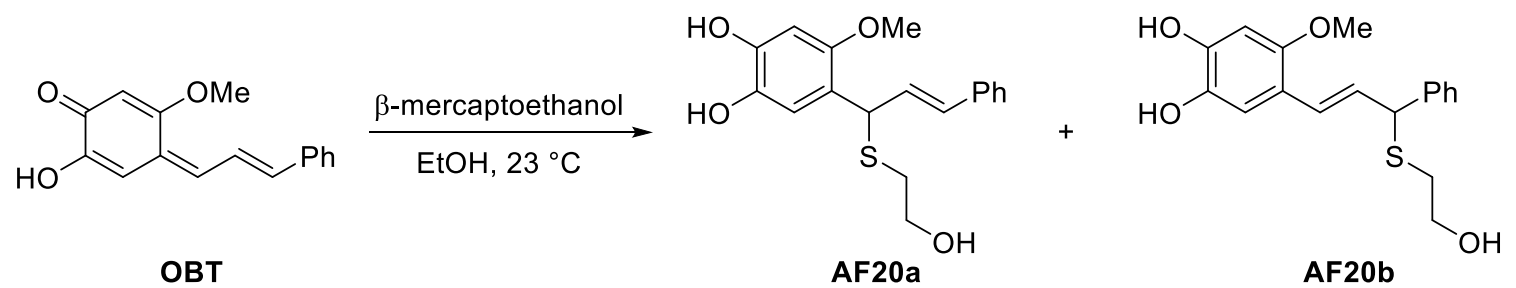

(E)-4-(1-((2-hydroxyethyl)thio)-3-phenylallyl)-5-methoxybenzene-1,2-diol (AF20a) and (E)-4(3-((2-hydroxyethyl)thio)-3-phenylprop-1-en-1-yl)-5-methoxybenzene-1,2-diol (AF20b): To a 20-mL flask containing a magnetic stir bar was added obtusaquinone (10 mg, $0.0393 \mathrm{mmol})$, absolute $\mathrm{EtOH}(2 \mathrm{~mL})$, and $\beta$-mercaptoethanol (8 uL, $0.114 \mathrm{mmol}$ ). Over the course of the reaction, the sparingly-soluble orange solid is converted to the adduct, which is homogenous in absolute EtOH and gives rise to a light yellow homoegenous solution. After $1 \mathrm{~h}$, analysis by LCMS indicated that the reaction was not complete, aditional $\beta$-mercaptoethanol $(4 \mathrm{uL}, 0.057 \mathrm{mmol})$ was added. At $\mathrm{t}=2 \mathrm{~h}$, the reaction was complete. The solution is concentrated and dried under high vacuum to yield the desired product as amber oil with AF20a as the major regioisomer $(\sim 10: 1)$ Regioisomer A: 1H NMR (400 MHz, MeOD) $\delta 7.36(\mathrm{~d}, \mathrm{~J}=8.0 \mathrm{~Hz}, 2 \mathrm{H}), 7.26(\mathrm{t}, \mathrm{J}=7.5 \mathrm{~Hz}, 2 \mathrm{H})$, $7.18(\mathrm{~d}, \mathrm{~J}=7.4 \mathrm{~Hz}, 1 \mathrm{H}), 6.89(\mathrm{~s}, 1 \mathrm{H}), 6.46(\mathrm{~s}, 1 \mathrm{H}), 6.45(\mathrm{~d}, \mathrm{~J}=15.6,1 \mathrm{H}), 6.33(\mathrm{dd}, \mathrm{J}=15.6,8.4$ $\mathrm{Hz}, 1 \mathrm{H}), 5.02(\mathrm{~d}, \mathrm{~J}=8.4 \mathrm{~Hz}, 1 \mathrm{H}), 3.74(\mathrm{~s}, 3 \mathrm{H}), 3.62(\mathrm{t}, \mathrm{J}=7.2 \mathrm{~Hz}, 2 \mathrm{H}), 2.59-2.43(\mathrm{~m}, 1 \mathrm{H})$. 13C NMR (101 MHz, MeOD) $\delta 151.6,146.3,140.2,138.4,131.5,131.0,129.6,128.5,127.4$, 120.6, 116.3, 101.7, 62.4, 57.0, 45.3, 34.8.

MS (ESI $\left.{ }^{-}\right) \mathrm{m} / \mathrm{z}(\mathrm{M}-\mathrm{H})^{-}$331.28, [calculated $\mathrm{C}_{18} \mathrm{H}_{19} \mathrm{O}_{4} \mathrm{~S}:$ 331.1]. 

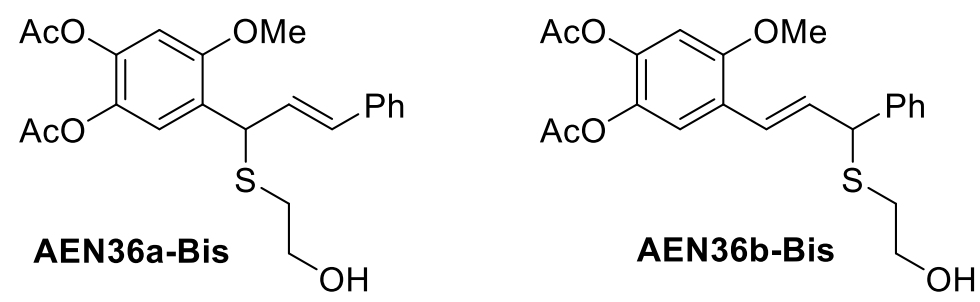

(E)-4-(1-((2-hydroxyethyl)thio)-3-phenylallyl)-5-methoxy-1,2-phenylene diacetate (AEN36aBis) and (E)-4-(3-((2-hydroxyethyl)thio)-3-phenylprop-1-en-1-yl)-5-methoxy-1,2-phenylene diacetate (AEN36b-Bis): To a 20-mL flask containing a magnetic stir bar and AF20 was added pyridine (786 uL, $0.05 \mathrm{M}$ ) and $\mathrm{Ac}_{2} \mathrm{O}(7.4 \mathrm{uL}, 0.786 \mathrm{mmol})$. After $16 \mathrm{~h}$, additional $\mathrm{Ac}_{2} \mathrm{O}(1.5 \mathrm{uL}$, $0.0159 \mathrm{mmol}$ ) was added. At $\mathrm{t}=18.5 \mathrm{~h}$, the reaction was completed as judged by LCMS. The reaction mixture was concentrated to afford an amber oil. Purified by flash column chromatography $\left(0 \rightarrow 5 \% \mathrm{MeOH} / \mathrm{CH}_{2} \mathrm{Cl}_{2}\right)$ to afford a 1:0.24 mixture of AEN36a-Bis and AEN36bBis (5.2 $\mathrm{mg}, 32 \%$ ) as a yellow oil, which eventually equilibrated at room temperature in CDCl3 to a 1:1.4 mixture of both isomers. Regioisomer $\mathrm{A}:{ }^{1} \mathrm{H}$ NMR $\left(400 \mathrm{MHz}, \mathrm{CDCl}_{3}\right) \delta 7.47-7.19(\mathrm{~m}, 6 \mathrm{H})$, $6.73(\mathrm{~s}, 1 \mathrm{H}), 6.56(\mathrm{~d}, J=15.6 \mathrm{~Hz}, 1 \mathrm{H}), 6.33(\mathrm{dd}, J=15.7,8.2 \mathrm{~Hz}, 1 \mathrm{H}), 5.07(\mathrm{~d}, J=8.4 \mathrm{~Hz}, 1 \mathrm{H})$, $3.86(\mathrm{~s}, 3 \mathrm{H}), 3.72(\mathrm{t}, \mathrm{J}=5.9 \mathrm{~Hz}, 2 \mathrm{H}), 2.71(\mathrm{~m}, 2 \mathrm{H}), 2.29(\mathrm{~s}, 3 \mathrm{H}), 2.27(\mathrm{~s}, 3 \mathrm{H})$.

${ }^{13} \mathrm{C}$ NMR $\left(101 \mathrm{MHz}, \mathrm{CDCl}_{3}\right) \delta 168.6,168.2,154.3,141.5,136.4,135.4,131.7,128.6,127.8$, $127.6,127.0,126.5,122.9,106.4,60.5,56.2,43.6,34.8,20.7,20.6$.

Regioisomer B: ${ }^{1} \mathrm{H}$ NMR $\left(400 \mathrm{MHz}, \mathrm{CDCl}_{3}\right)$ ठ $7.46-7.19(\mathrm{~m}, 6 \mathrm{H}), 6.77(\mathrm{~s}, 1 \mathrm{H}), 6.74(\mathrm{~d}, \mathrm{~J}=15.8$ $\mathrm{Hz}, 1 \mathrm{H}), 6.31(\mathrm{dd}, J=15.8,9.1 \mathrm{~Hz}, 1 \mathrm{H}), 4.64(\mathrm{~d}, J=9.1 \mathrm{~Hz}, 1 \mathrm{H}), 3.81(\mathrm{~s}, 3 \mathrm{H}), 3.72(\mathrm{t}, J=5.9 \mathrm{~Hz}$, $2 \mathrm{H}), 2.82-2.58(\mathrm{~m}, 2 \mathrm{H}), 2.29(\mathrm{~s}, 3 \mathrm{H}), 2.27(\mathrm{~s}, 3 \mathrm{H})$.

${ }^{13} \mathrm{C}$ NMR $\left(101 \mathrm{MHz}, \mathrm{CDCl}_{3}\right) \delta 168.7,168.2,154.6,141.8,140.1,135.4,130.6,128.8,127.9$, $127.7,124.7,124.0,120.9,106.3,60.6,56.0,52.2,34.8,20.7,20.6$.

MS $\left(\mathrm{ESI}^{+}\right) \mathrm{m} / \mathrm{z}(\mathrm{M}+\mathrm{Na})^{+} 439.12$, [calculated $\mathrm{C}_{22} \mathrm{H}_{24} \mathrm{NaO}_{6} \mathrm{~S}: 439.1$ ]. 


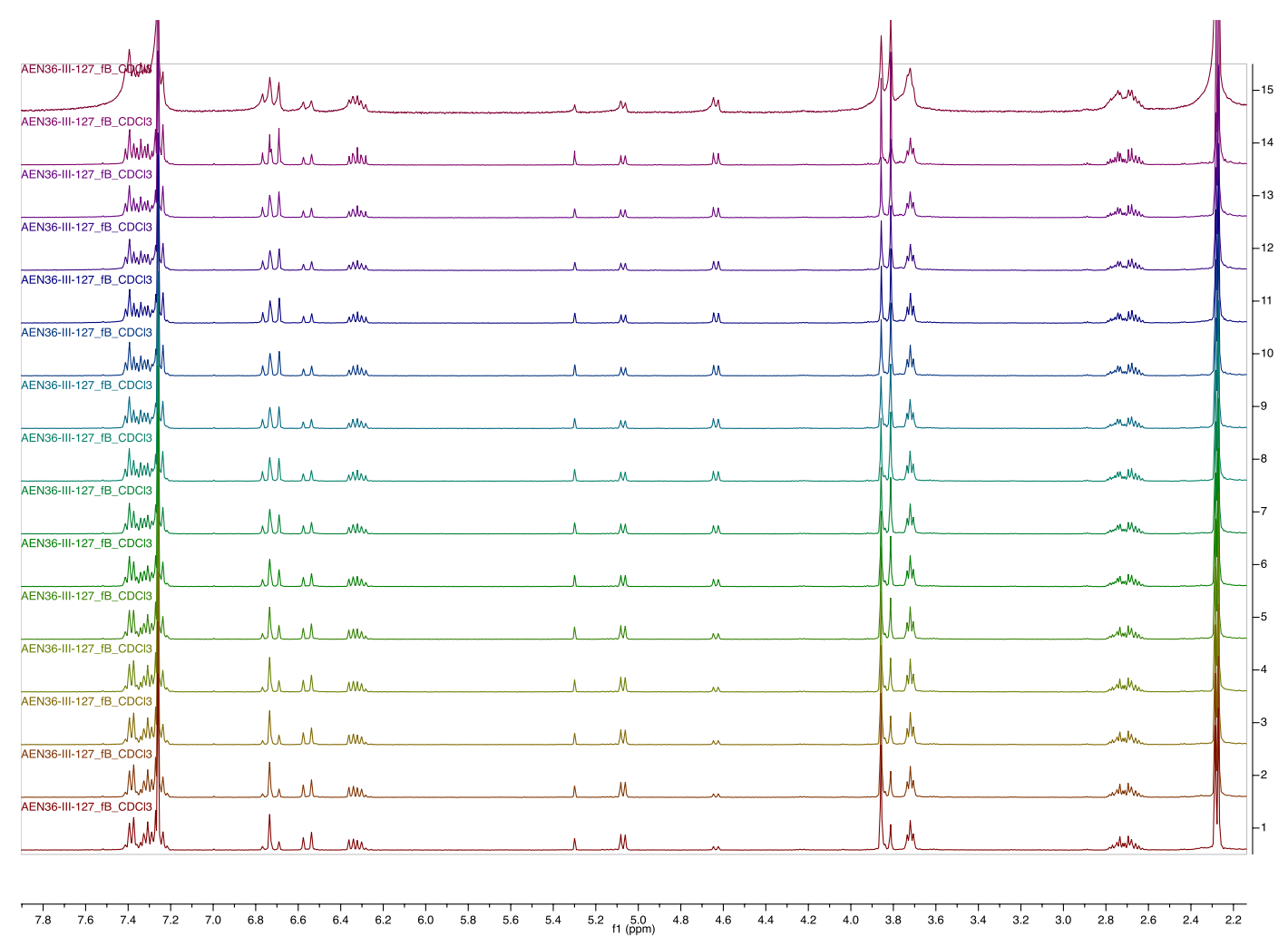

\begin{tabular}{|c|c|c|c|c|c|}
\hline & & & & raw & normalized \\
\hline & $t(h)$ & $\begin{array}{l}\text { int of } \\
\text { I1 }\end{array}$ & $\begin{array}{c}\text { int of } \\
12\end{array}$ & ratio $12 /(11+12)$ & ratio $12 /(11+12)$ \\
\hline $\mathrm{F}$ & 0 & 1 & 0.24 & 0.193548387 & 0 \\
\hline $\mathrm{F}$ & 0.083333333 & 1 & 0.24 & 0.193548387 & 0 \\
\hline $\mathrm{F}$ & 0.25 & 1 & 0.28 & 0.21875 & 0.025201613 \\
\hline $\mathrm{F}$ & 0.5 & 1 & 0.33 & 0.248120301 & 0.054571914 \\
\hline $\mathrm{F}$ & 1 & 1 & 0.43 & 0.300699301 & 0.107150914 \\
\hline $\mathrm{F}$ & 2 & 1 & 0.67 & 0.401197605 & 0.207649218 \\
\hline $\mathrm{F}$ & 3 & 1 & 0.87 & 0.465240642 & 0.271692255 \\
\hline
\end{tabular}




\begin{tabular}{|l|c|c|c|c|c|}
\hline $\mathrm{F}$ & 5 & 1 & 1.12 & 0.528301887 & 0.3347535 \\
\hline $\mathrm{F}$ & 8 & 1 & 1.27 & 0.559471366 & 0.365922979 \\
\hline $\mathrm{F}$ & 12 & 1 & 1.33 & 0.570815451 & 0.377267064 \\
\hline Sun & 48 & 1 & 1.34 & 0.572649573 & 0.379101186 \\
\hline $\mathrm{M}$ & 72 & 1 & 1.34 & 0.572649573 & 0.379101186 \\
\hline $\mathrm{T}$ & 96 & 1 & 1.35 & 0.574468085 & 0.380919698 \\
\hline W & 120 & 1 & 1.35 & 0.574468085 & 0.380919698 \\
\hline Th & 144 & 1 & 1.39 & 0.581589958 & 0.388041571 \\
\hline
\end{tabular}<smiles>COc1cc(OC(C)=O)c(OC(C)=O)cc1C(/C=C/c1ccccc1)SCCOC(C)=O</smiles><smiles>COc1cc(OC(C)=O)c(OC(C)=O)cc1/C=C/C(SCCOC(C)=O)c1ccccc1</smiles>

(E)-4-(1-((2-acetoxyethyl)thio)-3-phenylallyl)-5-methoxy-1,2-phenylene diacetate (AEN36aTris) and (E)-4-(3-((2-acetoxyethyl)thio)-3-phenylprop-1-en-1-yl)-5-methoxy-1,2-phenylene diacetate (AEN36b-Tris): To a 20-mL flask containing a magnetic stir bar and $155 \mathrm{mg}(0.39$ mmol) AF20 was added $5 \mathrm{~mL}$ pyridine and $160 \mu \mathrm{L} \mathrm{Ac} 2 \mathrm{O}(1.6 \mathrm{mmol})$ and stirred overnight. The solution was concentrated and dried under high vacuum to yield the desired product as amber oil with AEN36a-Tris as the major regioisomer ( 10:1). Flash column chromatography $(0 \rightarrow 10 \%$ $\mathrm{MeOH} / \mathrm{CH}_{2} \mathrm{Cl}_{2}$ ) afforded the desired products as a yellow oil as mixtures of regioisomers (170mg, 95\%)

Regioisomer A: ${ }^{1} \mathrm{H}$ NMR (400 MHz, CDCl3) $\delta 7.38$ - $7.23(\mathrm{~m}, 6 \mathrm{H}), 6.73(\mathrm{~s}, 1 \mathrm{H}), 6.54$ (d, J = 15.6 $\mathrm{Hz}, 1 \mathrm{H}), 6.29(\mathrm{dd}, \mathrm{J}=15.6,8.6 \mathrm{~Hz}, 1 \mathrm{H}), 5.12(\mathrm{~d}, \mathrm{~J}=8.6 \mathrm{~Hz}, 1 \mathrm{H}), 4.29-4.16(\mathrm{~m}, 2 \mathrm{H}), 3.84(\mathrm{~s}$, 3H), $2.71(\mathrm{~m}, 2 \mathrm{H}), 2.28(\mathrm{~s}, 3 \mathrm{H}), 2.27(\mathrm{~s}, 3 \mathrm{H}), 2.06(\mathrm{~s}, 3 \mathrm{H})$. 
MS $\left(\mathrm{ESI}^{+}\right) \mathrm{m} / \mathrm{z}(\mathrm{M}+\mathrm{H})^{+}$459.3, [calculated $\mathrm{C}_{24} \mathrm{H}_{26} \mathrm{NaO}_{7} \mathrm{~S}: 458.14$ ].

\section{Differential Alkylation for OBT Binding Characterization}

$10 \mu \mathrm{g}$ of bovine catalase (Sigma-Aldrich) were suspended in $100 \mu \mathrm{l}$ of $50 \mathrm{mM} \mathrm{HEPES} \mathrm{(pH} \mathrm{8.5)/0.5}$ $\%$ SDS and OBT, iodoacetamide (IAA), or N-ethylmaleimide (NEM) was added to a final concentration of $5 \mathrm{mM}$ and the mixtures were incubated for $30 \mathrm{~min}$ at RT in the dark before adding IAA to all three reactions to a final concentration of $10 \mathrm{mM}$ in the sample treated with IAA in the first alkylation step, and of $5 \mathrm{mM}$ in the other two samples. Upon incubation at RT for $30 \mathrm{~min}$ in the dark dithiothreitol (DTT) was added to all reaction to a final concentration of $20 \mathrm{mM}$ and the reactions were first incubated at $\mathrm{RT}$ in the dark for $15 \mathrm{~min}$ and then at $56^{\circ} \mathrm{C}$ for $30 \mathrm{~min}$. Then, NEM was added to all reactions to a final concentration of $100 \mathrm{mM}$ followed by incubation at RT in the dark for $30 \mathrm{~min}$. The experiments were done in triplicate. Samples were analyzed by mass spectrometry as described below.

\section{Quantitative Proteomics}

Cell pellets were lysed in a buffer of $75 \mathrm{mM} \mathrm{NaCl}, 50 \mathrm{mM}$ HEPES $\mathrm{pH} 8.5,10 \mathrm{mM}$ sodium pyrophosphate, $10 \mathrm{mM}$ sodium fluoride, $10 \mathrm{mM} \beta$-glycerophosphate, $10 \mathrm{mM}$ sodium orthovanadate, 10 mM PMSF, Roche complete mini EDTA free protease inhibitors (1 tablet per $20 \mathrm{ml}$ ), and $3 \%$ SDS. Lysis was achieved by passing the suspension through a 21 -gauge needle 20 times. Proteins were prepared for proteomics analysis as described previously ${ }^{5}$. Proteins from the lysates or the differential alkylation experiments were reduced with DTT; free thiols were alkylated with iodoacetamide; proteins were purified by $\mathrm{MeOH} / \mathrm{CHCl}_{3}$ precipitation and digested with Lys-C and trypsin, and peptides were labeled with TMT-10plex reagents (Thermo Scientific) 6.

Labeled peptide mixtures were pooled, and for the cell line samples, they were fractionated by basic reversed-phase HPLC as described previously ${ }^{5}$. Twelve fractions were analyzed by 
multiplexed quantitative proteomics performed on an Orbitrap Fusion mass spectrometer (Thermo Scientifc) using a Simultaneous Precursor Selection (SPS) based MS3 method ${ }^{7}$. Proteins from the differential alkylation experiments were not fractionated prior to analysis by mass spectrometry. MS2 spectra were assigned using a SEQUEST-based ${ }^{8}$ proteomics analysis platform ${ }^{9}$. Cysteine residues were allowed to either carry an IAA (mass increment, 57.021464) or an NEM remnant (mass increment, 229.162932). Peptide and protein assignments were filtered to a false discovery rate of $<1 \%$ employing the target-decoy database search strategy ${ }^{10}$ and using linear discriminant analysis and posterior error histogram sorting ${ }^{9}$. Peptides with sequences contained in more than one protein sequence from the UniProt database were assigned to the protein with most matching peptides ${ }^{9}$. We extracted TMT reporter ion intensities as those of the most intense ions within a 0.03 Th window around the predicted reporter ion intensities in the collected MS3 spectra. For the cell line samples only MS3 with an average signal-to-noise value of larger than 40 per reporter ion as well as with an isolation specificity ${ }^{11}$ of larger than 0.75 were considered for quantification. Only isolation specificity filetring was used

when analyzing the data from the differential alkylation experiments. A two-step normalization of the protein TMT-intensities was performed by first normalizing the protein intensities over all acquired TMT channels for each protein based on the median average protein intensity calculated for all proteins. To correct for slight mixing errors of the peptide mixture from each sample a median of the normalized intensities was calculated from all protein intensities in each TMT channel and the protein intensities were normalized to the median value of these median intensities. For the samples from the differential alkylation experiments the latter normalization was done only considering peptides not carrying a cysteine residue.

\section{RAW DATA DEPOSITORY:}

Bovine catalase: This is an experiment to use differential cysteine alkylation to map the nature of binding of a cysteine-targeting small molecule OBT (for details of the method, please see the 
Method Section of the manuscript). The alkylating reagents used besides the studied drug were iodoacetamide (IAA) and $\mathrm{N}$-ethylmaleimide (NEM). As described in the manuscript the experiment includes three routes of serial alkylation experiments termed OBT, IAA, and NEM. Samples were prepared in triplicate and TMT10-plex reagents were used for labeling as follows: OBT replicate 1 (OBT1), 129c; OBT2, 130n; OBT3, 130c; IAA1, 126; IAA2, 127n; IAA3, 127c; NEM1, 128n; NEM2, 128c; NEM3, 129n.

The RAW file for these data is: ol04291_RA_180809_OBT_TMT1.

A differential alkylation experiment was also performed as described above for bovine catalase but using recombinant human KEAP1 as substrate. One set of experiments (OBT, IAA, NEM) was performed. TMT10-plex labeling was performed as follows: OBT, 129n; IAA, 128c; NEM, $128 n$.

The RAW file for these data is: wh06977_MB_Chris_TMT7_112415

Modifications:

static: $229.162932(\mathrm{TMT}), 57.02146374(\mathrm{IAA})$

variable: 15.9949146221 (oxidation, M), 68.026215 (NEM, in addition to IAA (static)) 


\section{REFERENCES}

1. Badr, C.E., et al. Real-time monitoring of nuclear factor kappaB activity in cultured cells and in animal models. Molecular imaging 8, 278-290 (2009).

2. Furukawa, M. \& Xiong, Y. BTB protein Keap1 targets antioxidant transcription factor Nrf2 for ubiquitination by the Cullin 3-Roc1 ligase. Molecular and cellular biology 25, 162-171 (2005).

3. Maguire, C.A., et al. Triple bioluminescence imaging for in vivo monitoring of cellular processes. Molecular therapy. Nucleic acids 2, e99 (2013).

4. Badr, C.E., Hewett, J.W., Breakefield, X.O. \& Tannous, B.A. A highly sensitive assay for monitoring the secretory pathway and ER stress. PloS one 2, e571 (2007).

5. Edwards, A. \& Haas, W. Multiplexed Quantitative Proteomics for High-Throughput Comprehensive Proteome Comparisons of Human Cell Lines. Methods Mol Biol 1394, 113 (2016).

6. McAlister, G.C., et al. Increasing the multiplexing capacity of TMTs using reporter ion isotopologues with isobaric masses. Analytical chemistry 84, 7469-7478 (2012).

7. McAlister, G.C., et al. MultiNotch MS3 enables accurate, sensitive, and multiplexed detection of differential expression across cancer cell line proteomes. Analytical chemistry 86, 7150-7158 (2014).

8. $\quad$ Eng, J.K., McCormack, A.L. \& Yates, J.R. An approach to correlate tandem mass spectral data of peptides with amino acid sequences in a protein database. J Am Soc Mass Spectrom 5, 976-989 (1994).

9. Huttlin, E.L., et al. A tissue-specific atlas of mouse protein phosphorylation and expression. Cell 143, 1174-1189 (2010).

10. Elias, J.E. \& Gygi, S.P. Target-decoy search strategy for increased confidence in largescale protein identifications by mass spectrometry. Nature methods 4, 207-214 (2007).

11. Ting, L., Rad, R., Gygi, S.P. \& Haas, W. MS3 eliminates ratio distortion in isobaric multiplexed quantitative proteomics. Nature methods 8, 937-940 (2011). 